\title{
Becoming a region, becoming global, becoming imperceptable: territorialising salmon in Chilean Patagonia
}

Article

Accepted Version

Blanco, G., Arce, A. and Fisher, E. (2015) Becoming a region, becoming global, becoming imperceptable: territorialising salmon in Chilean Patagonia. Journal of Rural Studies, 42. pp. 179-190. ISSN 0743-0167 doi:

https://doi.org/10.1016/j.jrurstud.2015.10.007 Available at https://centaur.reading.ac.uk/45629/

It is advisable to refer to the publisher's version if you intend to cite from the work. See Guidance on citing.

To link to this article DOI: http://dx.doi.org/10.1016/j.jrurstud.2015.10.007

Publisher: Elsevier

All outputs in CentAUR are protected by Intellectual Property Rights law, including copyright law. Copyright and IPR is retained by the creators or other copyright holders. Terms and conditions for use of this material are defined in the End User Agreement.

www.reading.ac.uk/centaur 
Central Archive at the University of Reading

Reading's research outputs online 


\title{
Becoming a Region, Becoming Global, Becoming Imperceptible: Territorialising Salmon in Chilean Patagonia
}

\author{
Gustavo Blanco \\ Instituto de Historia y Ciencias Sociales \\ Universidad Austral de Chile \\ Campus Isla Teja s/n \\ Casilla 567 \\ Valdivia \\ Chile \\ gblanco@uach.cl \\ +56-63-2221547
}

Alberto Arce [corresponding author]

Sociology of Development and Change Group

Hollandsweg 1

$6701 \mathrm{KN}$

Wageningen

The Netherlands

alberto.arce@wur.nl

+31-317-482497

Eleanor Fisher

School of Agriculture, Policy and Development

Agricultural Building

Earley Gate, Whiteknights

PO Box 237

Reading RG6 6AR

United Kingdom

e.fisher@ reading.ac.uk

+44-118-3788883 


\title{
Becoming a Region, Becoming Global, Becoming Imperceptible: Territorialising Salmon in Chilean Patagonia
}

\begin{abstract}
Our article focuses on the region of Chilean Patagonia and considers how it has developed as a leading producer of salmon for global food markets. It addresses the problem of how to decentre conventional views of the forces driving regional development that give primacy to the role of capital and technology, instead giving due recognition to the knowledge and practices of situated actors and to the relationships that form between human and non-human entities in food producing regions. As an alternative, we ask whether an assemblage approach can improve our understanding of regional transformation. To explore this question, we present original ethnographic data on constitutive practices that have transformed the Patagonian region, from the territorialization of Salmonidae species to experimentation in ocean ranching and sea water fish farming, and finally the development of a global industry. The evidence leads us to argue that in a complex globalised world, assemblage theory offers a valuable approach for understanding how regional potential is realised. In the case of Chilean Patagonia, it is apparent that forms of bio-power generate new relations between life, agency and nature, stimulating contemporary regional transformations in ways overlooked by the lineal logic of capital objectification discourses. Applying an assemblage approach enables the significance of new contemporary human non-human relationships and inter-subjectivities to come to the fore, keeping the social in view as potential for regional transformation and new power asymmetries continuously emerge.
\end{abstract}

Keywords: assemblage theory; inter-subjectivity; ethnography; Chile; salmon production 


\section{INTRODUCTION}

In this article, we explore how Chilean Patagonia has become the site of salmon production for global markets. Using assemblage theory, we consider how the region's potential has been transformed, as an association of entities - an assemblage - has emerged and generates future potential. As our nod to Deleuze and Guattari (1988: 232 Becoming-Intense, Becoming-Animal, Becoming-Imperceptible) in the title implies, we challenge the simplicity of cause and effect understandings of regional transformation and instead locate the region as a social field marked by fluidity and shifting power relations, one in which contemporary biopower - whereby bio-genetic resources are pre-requisites for quality attributes - stimulates new human - non-human alliances and inter-subjectivities between people and salmon.

Chilean aquaculture is identified as an exemplary technical innovation within a national export-oriented economy (Bjørndal and Aarland, 1999; Katz, 2004). The nature of industrial configuration, technological development, markets and labour are considered critical to success (e.g. Amtmann and Fecci, 2008; Montero, 2004; Vergara et al., 2004), despite environmental and social concerns being raised (Barrett et al., 2002; Barton, 1997; Buschmann, 2005; Blanco, 2009; Blanco and Amtmann, 2001; Claude and Oporto, 2000; Gajardo and Lairke, 2003; Lindbergh, 1999; Niklitschek et al., 2013). We would argue that, while important, a portrait of the country as a major global player through economic development driven by technology and capital - i.e. the neoliberal discourse of the Chilean state - carries the danger of detaching salmon, people and environment from the particular conjunctures of circumstances, events and relationships that are integral to regional change. 
From our perspective, a restricted view of regional development emerges when capitalist and technological processes of accumulation are emphasised at the expense of recognition given to other entities. As we hope to demonstrate, this matters because the Chilean salmon industry is a capitalist regional formation that appropriates the labour and livelihood of situated actors. Recognising these processes of appropriation, how different actors are incorporated into the lifeblood of production for global markets, is significant for empirical research partly because the objectivising capacity of capitalism marginalises people from the creative potential of their practices to the detriment of the equitable distribution of regional benefits, but also because bringing local actors into view exposes the potential for new and different trajectories of regional change (c.f. Braun, 2014).

Therefore, the research problem this article seeks to address is how to 'decentre' conventional views of the forces driving regional development and to examine the territorial (re)organisation of a region in ways that permit due recognition to be given to the all too often overlooked circumstances, events and relationships that are an integral part of commodity production. This leads us to question whether an assemblage approach that is sensitive to inter-subjectivity can improve our understanding of regional transformation for global food production. To tackle these issues, we revisit the development of salmon production in Chilean Patagonia through the nineteenth, twentieth and early twenty-first centuries. In so doing we hope to give due recognition to the social within the complex new relationships that form between human and non-human entities in an era of biogenetic manipulation of quality attributes for global food markets, our rationale being that human practice and creativity are found within these junctures, exposing processes of inter-subjectivity. ${ }^{1}$

\footnotetext{
${ }^{1}$ Inter-subjectivity refers to alliances that are formed at an interface whereby entities ('real' or not) construct, reconstruct and dismantle themselves as they cross each other's boundaries to constitute new individualities, be this linguistic or corporeal, capable of generating a degree of power or potential (Deleuze and Guattari, 1988).
} 
In keeping with an assemblage approach, we describe the trajectories of regional change examined in this article as lines of flight (ligne de fuite) - acts flowing, fleeing, disappearing into the distance ${ }^{2}-$ which create potential for transformation, as a salmon producing region is assembled and dis-assembled. Allen et al. (1998) have argued that a region is a social construct, being a product of the combination and articulation of social relations within a spatial area. This opens up the possibility for regional entities to emerge rather than being taken as a given. In this vein and emphasising materiality, Metzger (2013) has asked how regional entities come to last and get taken for granted, a question relevant to our case. As we shall elaborate in Section Two, this thinking leads us to draw on Deleuze and Guattari (1988), to view a region as the correspondence of relations with resources and with how social life, institutions and political processes are played out as the sum of affect.

As salmon producing regions have grown up in different parts of the world, human - nonhuman relationships and materiality are stimulated by the growing significance of 'biopower', which feeds into the new regional dynamics. In extreme, drawing on Foucault (1978), bio-power reduces living bodies to being vital carriers of information, being power that takes life as an object that attracts financial value and capitalized investment (Braidotti, 2013). More moderately, bio-power encompasses how genetic manipulation and / or attention to genetic resources located in particular environments are considered pre-requisites for quality attributes, including coding and de-coding through DNA, plus the representation of resources as infinite due to gene manipulation, with salmon production being a case in

Through inter-subjectivity the experience of creativity is available not just to the individual but also to the (nonhuman) other, associating individuality, the social, the self, and the other.

${ }^{2} \mathrm{~A}$ line of flight (French: ligne de fuite) is a concept developed by Gilles Deleuze and used extensively in his work with Félix Guattari. In A Thousand Plateaus (1988: 7-25), the concept is used to define a 'rhizome': "Multiplicities are defined by the outside: by the abstract line, the line of flight or deterritorialization according to which they change in nature and connect with other multiplicities. 
point. Braidotti (2013: 116-7) argues that today we go beyond Foucault's analysis of the biopolitical and the control of bodies - from which original ideas of bio-power stem - with biopower being transformed in the contemporary era to the bio-genetic and farming of data. In effect, bio-power as we refer to it is not centralised control through bureaucracy (Foucault, 1978), but distributed through the neo-liberal market and the legitimisation of consumer demand for quality foodstuffs and fashionable commodities.

A focus on bio-power raises questions over how sociality is expressed in the relationship between human and non-human actors as they co-create and experience a shared regional reality in processes of becoming global. In our focus on regional transformation, the neoliberal objectification of regional alliances motivates our reflective (re)-turn to an examination of the material experience of human practice and creativity, pointing to the importance of the inter-subjective conditions of the human - non-human relationships. Our perspective does not seek to obliterate actors lived experience but instead calls for new forms of engagement within the social sciences, as the present reduction of the economic, cultural and political domains becomes more fluid and intimate, with human - non-human entities being part of a taken for granted social world.

Our discussion proceeds as follows: Section Two considers perspectives from the literature on salmon farming and trout fishing and outlines our conceptual approach. Section Three describes our methodology, while Section Four presents our case, which links secondary historical material on the introduction of the Salmonidae family to Chile to ethnographic research on salmon farming in Chilean Patagonia, focusing on Aysén (Region XI). Finally, Section Five, our discussion and conclusion, reflects on what an assemblage approach can contribute to an understanding of regional transformation. 


\section{SALMONIDAE: HETEROGENEITY AND TERRITORIALITY}

Data from our ethnographic research on salmon farming in Chilean Patagonia highlights inter-subjectivities that emerge between people and salmon as part of a process of bio-power creation that we would argue has become integral to regional transformation. Across the region, technologically intensive offshore pontoons incorporate sophisticated devices for ensuring the development of salmon of a quality appropriate to global markets. Each Pontoon is a floating three-storey structure, incorporating a watchtower, offices with ICT equipment, living quarters, and storage areas surrounded by in-sea net-pens. Fish feeding is controlled by software; with fish movements followed by submarine camera. Workers have a finely honed ability to interpret the fish behaviour they witness on screen (Figure 1), being able to tell when they are ill, hungry, nervous, overfed, with slow metabolism, etc.

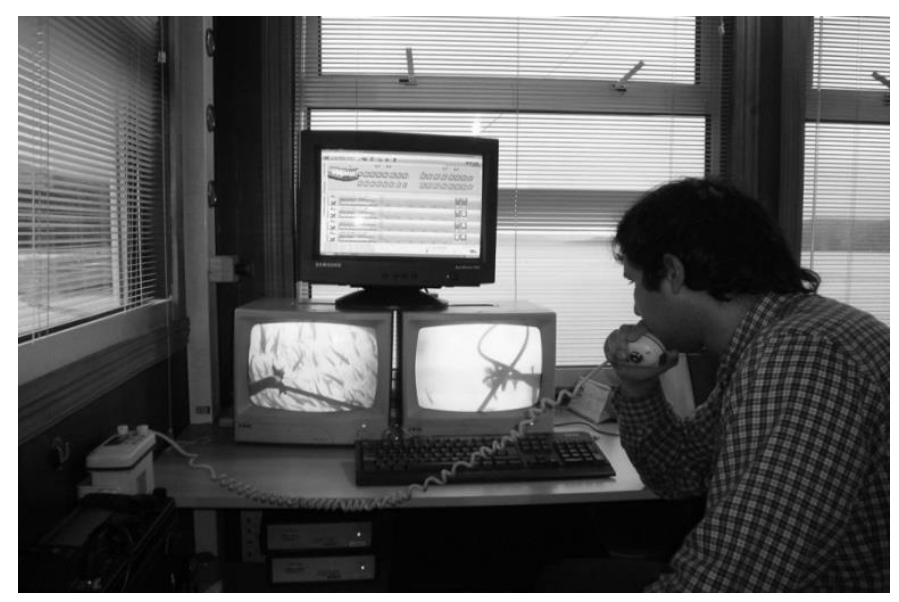

Figure 1: Worker monitoring salmon movement

The paraphernalia of technology present on the pontoon raises the question of how this work environment affects interactions between people and salmon. A small vignette illustrates 
relations emerging in daily working life: on one visit, the researchers observed a foreman hand-feeding salmon in a net-pen. As he went about his work, he reflected on the fish, saying that one of the surprising things was how when smolts are moved to the sea and introduced to the net-pen "they don't know they are fish". He went on to describe how the salmon were "like my own children that I need to tell how to act in real life". It was therefore up to him to hand-feed the smolts to teach them how to move together in a school. This is important because if the salmon could not circulate as a group they can't feed from the automatic machine.

In this vignette we have an intensive interaction between the foreman, the smolts, and a fishfeeding machine with encoded ideas on salmon movement. It captures the ability and capacity of different actors to participate in new relationships, connecting self to others, where these others also refer to the non-human (salmon, technology) in the social achievement of the material quality of the fish. This is a multi-species assemblage, a form of bio-power created in the service of capitalism, highlighting the reflexive significance to the act of labouring. In the process, acts of engagement are generated to provide background information, which breaks the link between impersonal rationality and quality for food markets. The illusion of the immediate understanding of the neoliberal experience feeds on these non-commoditised relations with the non-humans while at the same time excluding from the inquiry questions over the relevance of these social conditions for salmon production.

In grappling with how to view inter-subjectivity and regional change in ways that take into account local specificities and global multiplicities, while at the same time keeping human non-human relations in view, assemblage theory has utility in mapping how a social and 
material constituency forms around the salmon, expanding interactions beyond direct investment in the Chilean salmon industry. How theorists conceptualise an assemblage and the degree of emphasis placed on complexity ranges significantly, however assemblages can be understood to be wholes composed of heterogeneous external elements or objects that enter into relations with one another incorporating diverse actors across vast distances. Relations of exteriority mean that parts of the whole cannot be reduced to their function within the whole but instead are shaped by their interactions (De Landa, 2006).

Influenced by Deleuze and Guattari (1987) and later De Landa (2006), 'thinking with assemblage' (Mcfarlane and Anderson, 2011) has generated diverse scholarship that nonetheless shares commonalities in terms of a critique of lineal understandings of change and of approaches that see the world as constituted by a range of substantive objects in an order of hierarchy. Assemblage theory comes to the fore in research problematizing the form and content of global processes because it does not privilege one level of organisation over another, lending itself to analysis of the composition of multifarious elements within different expressions of multiple wholes (e.g. Ong and Collier, 2005; Dittmer, 2014; Li, 2007; Thrift, 2008). Thus 'thinking with assemblage' permits us to reconsider how heterogeneous configurations of actors come together within an understanding of the region as something other than a coherent context or bounded arena (Allen et al., 1998; Allen, 2011; Dittmer, 2014). In short, if well-conceived, an assemblage approach opens up new questions on life, nature and the social in a rapidly changing world (Allen, 2011).

\subsection{The potentiality of Salmonidae}

Species of salmon and trout are part of the Salmonidae family, which were introduced to the southern hemisphere for recreation and consumption purposes. There is a body of work on 
the territorialization of Salmonidae in different parts of the world that is relevant to this discussion. Drawing on a new materialist perspective, Franklin (2011) considers the acclimatization of Salmonidae in terms of the co-constitution of human and non-human relationships. Viewing trout fishing in Australia as performance, he argues that trout took an active part in the acclimatization process. A similar emphasis on salmon as actors is found in Lien's (2005) description of the role of Tasmanian Atlantic salmon in the creation of place, with practices, images and experiences sustaining hybrid networks of linkages between places. Knudsen's (2014) work on the sea snail Rapana venosa in Turkey and Silver's (2013, 2014) work on Pacific oysters and Manila clams in British Colombia coastal waters also emphasize shellfish as active participants in transformation and add to existing perspectives by stressing power and politics, conflict and negotiation.

In research on salmon farming in the fjords of Norway, Lien and Law (2011: 70) introduce the concept of the 'salmon multiple' to question binary thinking on nature and culture. Salmon are located as emergent, with salmon and nature performed together through relations of practice that create order and symmetry. Here are echoes of Ingold's (2011: 69) proposition on the primacy of being in the world, rather than detachment from it. In Ingold's view, beings are relationally constituted, with movement building a "trail along which life is lived" within a meshwork of interwoven lines. For Deleuze and Guattari (1988: 232 - 309), drawn on by Ingold, this potential is associated with the imperceptible: there is always movement in the throes of becoming without arriving at a determined point, reproducing relationships with other bodies across time and space, thus side-stepping resolution into objects and subjects (c.f. De Landa, 2006). 
In challenging taken-for-granted assumptions of regional change, our approach to assemblage theory draws from political ecology the notion of a 'flat ontology', in which heterogeneous elements are situated in symmetry (Bennett, 2010: 94-109; also Umans and Arce, 2014). A value of this methodological device is that it brings into view events and entities that are typically relegated to the role of externalities or marginalised from dominant perspectives, enabling one to rethink conceptual reference points in order to consider how the constitution of a global salmon region 'folds-in' external influences with a simultaneous 'folding-out' of affects and generation of new value (c.f. Van der Tuin and Dolphijn, 2010). Following Deleuze and Guattari (1988:12) we see these processes as generating new encounters and events that flow, leak, and become invisible in the neoliberal discourse of the Chilean state. While drawing on the notion of a 'flat ontology', we are nevertheless mindful that alongside questions of potential and contingency are issues of power: locating entities in symmetry is a useful methodological device to facilitate understanding of how lines of flight develop without pre-judging an order of importance; however we recognise that heterogeneous elements are rarely in symmetry. This issue is all too apparent within the power relations generated by new forms of bio-power in which new asymmetries are created within the region as part of a process of continuous reorganisation, rather than of reaching order.

While Lien and Law (2011) have proposed the 'salmon multiple' to capture how salmon and nature are performed within regimes of domestication, our attention turns towards a different plane, namely encounters between salmon and people within the constitution of a region. In the case of Chilean Patagonia, the salmon forms alliances with a public, created through different domestication practices - fish farming, angling, artisanal fishing, regional cuisine which each emerge from lines of flight (potentiality) created by Salmonidae's southern expansion, and incorporate generative categorisations of the world of experience. In this 
sense the propagation of a salmon-public plays out multiplicities with the capacity to transform themselves into one another and to spread their corporeality into regional public concerns.

Within this line of thinking, a methodological issue is how to tackle multiplicities in ways that retain the integrity of the social to understand it's malleability in relation to human and non-human materiality and affect. Lien and Law (2011) have argued that transgressions between established conceptual categories and associated acts of differentiation lead salmon and nature to be mutually constituted. This being the case it raises the question of where does the social now reside? While this article leans towards Deleuzian thinking, it is helpful to consider how Actor-Network Theory (ANT) has addressed the social. ANT has stimulated an extensive body of work that emphasizes the redistribution of notions of objectivity in the techno-scientific realm (Latour, 2005).

A long-standing critique of ANT relates to the 'generalized symmetry' postulated between humans and non-humans (subjects and objects) (Bloor, 1999; Colin and Yearley, 1992; Golinski, 1998). This critique has different aspects but here we would highlight one point, namely that more importance should be given to human agency and action. Krarup and Blok (2011: 42) focus on this point, arguing instead that "Latour may not be symmetrical enough in his dealings with objects and subjects, paying more attention to the former than the latter". Our starting point in focusing on the social, draws on Krarup and Blok's argument with reference to ANT, but which is equally pertinent to our discussion, namely that emphasis on a redistribution of objectivity has been at the expense of adequate attention to subjects and subjectivities (see Navaro-Yashin, 2009). Attempting to go beyond this shortcoming, Krarup and Blok (2011) bring issues of inter-subjectivity (human folds) to the fore, using the notion 
of the 'quasi-actant' to analyse the performance of subjectivity and put forward a theory of virtuality. This approach to inter-subjectivity strikes chords with earlier work by Arce and Long, (2000) in the field of development anthropology, where emphasis is placed on the concept of the interface and its use to describe how mutations - of entities, actors' subjectivities, etc. - confound established dichotomies to generate new expressions of modernity. The question of how we can keep subjectivities and inter-subjectivities in view comes to the fore in contemporary food production and the creation of bio-power, given that we live in an era of dramatic reassessment of what constitutes life, agency and nature, with a profound bearing on our understanding of the relationship between human and non-human actors.

Following Guattari (1995: 22), we propose to decentre the subject onto the question of intersubjectivity. For this we identify a quasi-actant that we nominate as the 'salmon-public'3, we define this as neither fish nor people but rather a mutation, with the public referring to a field of actors that emerge, co-exist and disappear as situations change, bringing to the fore dimensions of negotiation, conflict and fluidity that generate interfaces between groups (both human/people and non-human/salmon) (c.f. Bennett, 2010). Metzger (2013: 1369) following Marres (2005) has located 'the public' as heterogeneous and potentially dispersed actors that become attached to a specific issue within a region. While we don't disagree with this definition, our notion of the salmon-public is broader because it encompasses practices and

\footnotetext{
3 'Salmon-public' is an ethnographic concept influenced by the work of Bennett (2010) and the search for 'a new political ecology' that is multidimensional and able to reveal socio-environmental alliances between human and non-human actors. Lines of flight and deterritorialization influence alliances and change the nature of the salmon-public connecting to other multiplicities through multiple interactions and events. The concept focuses on potentiality through different events identified by ethnographic analysis. Anthropologists refer to "the Malinowski dilemma', reflecting on the problematic of the relationship between a conceptual framework developed 'after the event' as in the case of Malinowski and ethnographic studies. We are aware of this, there isn't an easy solution; the dilemma is neither resolved by sticking to existing perspectives nor through creating new concepts. Our argument is that the concept of the salmon-public permits us to rethink key issues of regional development and the dynamic of multiple actors that shape and transform social arenas and institutions associated with bio-power change.
} 
materiality generated through the intimate acquaintance that develops between the human and non-human as nothing less than the active exchange of affects, which can be seen as the events unfold and alliances are forge around the production of Chilean salmon. This holds the social as a material field, which expresses events that display regional precursors for the biopower assemblage.

Taking this approach raises the question of how these processes affect actors' intersubjectivity in processes of becoming. For Dewey (1954: 208) the answer is the improvement of the methods and conditions of debate, discussion and persuasion: that is the problem of the public. In this way the salmon-public can be characterised as a singular plurality, emphasising how situated actors receive, translate and rework messages, material resources and cultural repertoires, creating a plurality of actions for change in relation to wider influences. From our position, a conceptual axis between the salmon multiple and the salmon-public delineate capacities of different salmon producing regions. As with the material expression of salmon and nature (Lien and Law, 2011), the inter-subjective nature of the salmon-public territorializes salmon and people through practice.

In the following, we use assemblage theory to explore these issues, an outline of the methodology turn to people and environment particular conjunctures of circumstances, events and relationships on the introduction of salmon to Chilean Patagonia.

\section{METHODOLOGY}

Our methodology is based on an ethnographic approach, which is ideally suited to the study of "concrete social fields at specific moments" (Deleuze and Parnet 2002: 135). For anthropologists such as ourselves, ethnography is at the heart of our discipline; however we 
recognise that linking an assemblage approach to ethnographic inquiry raises interesting challenges for depiction of people, objects and environment. As Deleuze and Guattari (1994) discuss, there is a plethora of continual 'becomings' that the researcher interrupts at specific moments in an attempt to grasp dynamics. These challenges stimulate disciplinary dialogue without simple solutions recognising the need to grapple with complexity, requires cultivation of sensitivity to multiple ways in which situated practices, entanglements and nonhuman process intersect. This sensitivity to non-human processes often goes together with a desire to challenge rather than take for granted the self-organising force-fields of objects and subjects (c.f. Kohn, 2007: 14; Latour, 2005) to enquire on their variable capacities to morph.

Our ethnography uses four primary methods: semi-structured interviews, participant observation, and life/career histories. These methods help us to find, reveal and value relationships between local people and salmon based on practices that are otherwise 'unmarked' (Thrift 2008: 110) in portraits of the Chilean salmon industry. Research was undertaken in Chile for 12 months (2004-5), coupled with two short periods of data collection in Norway (2004 and 2005). ${ }^{4}$ A further month of data collection was undertaken in Chile by Blanco and Arce (2007). Participant observation in 2004-5 was conducted at 2 salmon farms, 1 pontoon, a salmon worker's camp, and the headquarters of a Chilean-owned company. Approximately 30 semi-structured interviews and 5 life/career histories were conducted during this period. In Norway, 10 key-informant interviews were undertaken and 2 fieldtrips made to the west coast of Sør-Trøndelag where salmon farming was observed in two companies. From this body of data we draw examples to illustrate our argument. ${ }^{5}$

\footnotetext{
${ }^{4}$ Fieldwork was funded by the Chilean Ministry of Education (Mecesup Project AUS208), the Ceres Innovative Research Program, Wageningen and the Office of Research and Development Universidad Austral (DID:S2005-63).

${ }^{5}$ See Blanco (2009) for further data.
} 
In Chile research was carried out in Puerto Cisnes (Aysén region), but trips were made to coastal settlements on the Archipelago of Las Guaitecas and the Region of Los Lagos (Figure 2). Locations were selected due to their growing importance in the southwards expansion of salmon farming, with Aysén being amongst the last areas of Chile to be colonised and the history of regional settlement can be retrieved through 2-3 generations of life histories. 


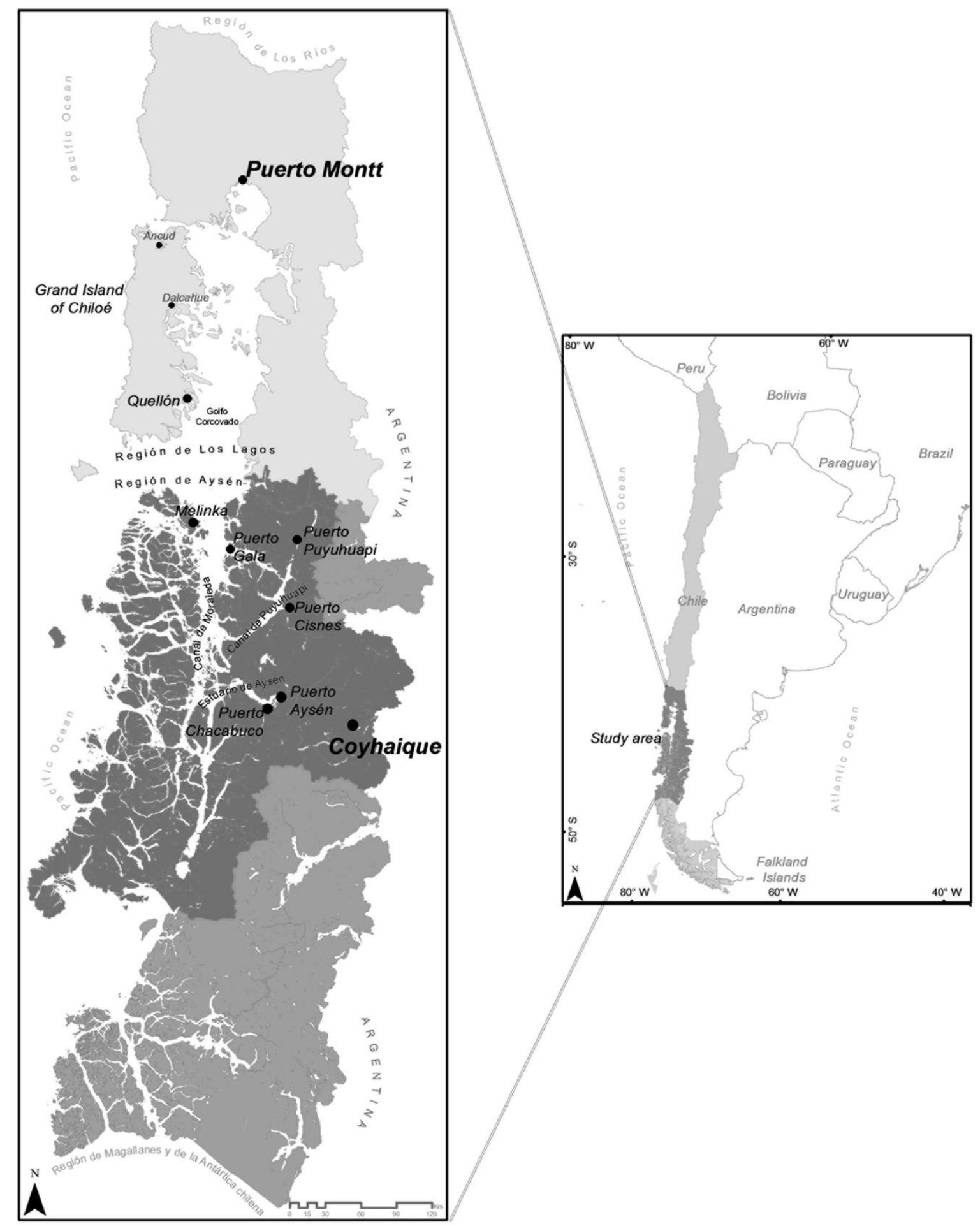

Figure 2: The study area with fieldwork locations (Region of Aysén)

\section{THE TERRITORIALIZATION OF SALMON IN THE REGION}


In exploring how a salmon-producing region has emerged, we seek to decentre narratives on the Chilean salmon industry, in which technology and capital are considered primary drivers for regional change. Instead, we map the multiplicity of circumstances, events and relationships through which assemblages emerge and a salmon-public is formed and flows as an expression of bio-power.

\subsection{A vacant ecological niche: The becoming of a salmon-public}

A report of 1848 on resources states: "Chile has a really low number of freshwater fish; in the Andean lakes there are none and only a few in the rivers of the central provinces..." (Aimé in Basulto, 2003: 19, our translation). It promoted the need to fill 'vacant ecological niches' (Lever, 1994: 3) driven by European recreational interests and the perceived lack of aggressiveness of native fish for fly fishing (Goycoolea and Sandoval, 2003: 41). After territorial reconnaissance, the National Society of Agriculture supervised the acclimatization of 'valuable' fish from Europe (Basulto 2003: 23-4). This biological translocation was facilitated by 'acclimatization societies' for alien species (Anderson 1997: 474; Dunlap 1997), dispersed as far afield as Tasmania, New Zealand and South Africa (Lien 2005: 663).

The first recorded attempt at Salmonidae translocation occurred in 1865: the newspaper El Correo del Sur welcomed efforts by wealthy coal miner Luis Cousiño to import eggs and acclimatize species in southern rivers. By 1903 historical accounts reported trout appearing in rivers, with an exemplar embalmed in the Chilean Museum of Natural History (Basulto 2003: 42-44). In 1897 the Scottish aquaculturist William Anderson Smith wrote a report for the Chilean government entitled: 'Introduction of Salmon in Chile'. Eight years later in 1905 government financed a fish hatchery in Rio Blanco (Central Chile) with further hatcheries in Maullín (1910) and Lautaro (1916). 
Burgeoning interest in the acclimatization of Salmonidae family declined; although there are records of seed salmon up to 1947 (Blanco, 2009: 126) attention to Salmonidae remained in abeyance until the latter half of the twentieth century, as described below. Nevertheless a set of affects laid potential for future salmon-publics within the region. Each becoming stimulates a game of boundaries, a process of ambiguity and imperceptibility, with the social repositioned in the ontology of quasi-actant, the salmon-public, in ways that will stimulate future territorialization related to the significance of bio-power. In the following, we map three events in the process of territorialisation of the salmon-producing region of Chilean Patagonia.

\subsection{Salmon experiments: Ocean ranching and sea water farming}

Salmonidae species continued a southern expansion through intermittent stocking initiatives and their own instigation (Blanco, 2009: 126-7), however interest in developing a Chilean fish industry only reawakened in the 1960s when potential for commercial development through scientific means was raised by government agencies and international development organisations. Joint efforts sought to introduce salmon through ocean ranching; in the process, the specialization of government agencies increased and a global exchange of aquaculture techniques, technology, and fish eggs was triggered, stimulating flows of information, people and materials to enter regional development.

Amongst the international organisations working in Chile between the 1960s and 1980s, the Japanese Fisheries Association was significant (funded by the Japanese International Cooperation Agency [JICA] (Shimazu and Puchi, 1985; Basulto, 2003; Vergara et al., 
2004). ${ }^{6}$ The regions of Los Lagos and Aysén became a focus for experiments with the release of four species of Pacific salmon (Shimazu and Puchi, 1985; Basulto, 2003: 217). ${ }^{7}$ Until the early 1980s these experiments focused on 'sea ranching', ${ }^{8}$ producing extensive scientific data and developing local expertise on fish breeding. However as techniques of confined salmon farming evolved in Japan and Norway, there was a decisive turn towards fish farming in net-pens building on knowledge generated through the ranching experiments.

The 1980s also heralded the entry of the private sector into Chilean salmon production. Fundación Chile, a public-private consortium for the promotion of technological innovation, became the first organisation promoting salmon production at seawater farms under the name Salmones Antártica. This was followed by Mares Australes, which began to farm Pacific salmon in the Pescado river of Los Lagos region. Another nine companies began their operations between 1983 and 1984. Up to 1985 fish farming attempts were on a low scale and located in Los Lagos region. However, the second half of the decade brought an export consolidation phase and companies raced to obtain aquaculture concessions, targeting Aysen region and towns connected to a recently opened highway to ensure wage labour and a logistic base.

Emerging alliances between people and salmon, in particular the roles played by local people are overlooked in literature on regional change. We capture this role through the example of two women, Doña Eugenia and Doña Quina, who were significant in the introduction of

\footnotetext{
${ }^{6}$ Between 1969 and 1986 the JICA-FHD project seeded 15.5 million chum salmon, 2.9 million pink salmon, 1 million of cherry salmon and 0.5 million of coho in the lakes and rivers of Aysén (Shimazu and Puchi, 1985).

${ }^{7}$ These species were chum salmon (Oncorhynchus keta), cherry salmon (Oncorhynchus masou), silver salmon or coho (Oncorhynchus kisutch) and pink salmon (Oncorhynchus gorbuscha) (Shimazu and Puchi, 1985).

${ }^{8}$ An early technological change in salmon production involved transformation in how salmon production was perceived, from the notion of 'ranching' to that of 'farming'. In 1969 the first sea water net-pen ${ }^{8}$ was created in Denmark. This technological development permitted low cost replication, led to spatial transition from land to sea-based production, and facilitated standardization and regulation (Aarset, 1998; Forster 2002).
} 
salmon farming to Aysen. Doña Eugenia was a mayor of Puerto Cisnes who encouraged the Japanese to introduce salmonid to Aysen. A few years later, Doña Quina was crucial in helping the first company to settle on the coastline of Puerto Cisnes.

In 1981 Doña Eugenia heard of a salmon-release experiment being carried out by the Japan International Cooperation Agency and the Chilean fisheries authorities near Coihayque. She convinced the researchers to run an experiment in the bay of a small settlement at Puerto Cisnes and enrolled a teacher to run a course called 'Marine Resources'. Doña Eugenia contacted personnel from the Institute for Fisheries Development (IFOP) and offered to hire two caretakers under the supervision of a teacher. It was agreed that salmon fingerlings, feed supplies, materials, and an experimental cage would be provided. The teacher was trained to measure fish growth and a small cage of $5 \times 5 \times 5$ meters was built from cypress wood, known locally for its resistance to water, with metal barrels acted as floats. Here we see an alliance has formed between people and salmon, building the constitution of a salmon-public. In 1982 they started breeding varieties of Pacific salmon, including: cherry salmon (Oncorhynchus masou), coho (Oncorhynchus kisutch) and rainbow trout (Oncorhynchus mykiss). According to the teacher, the most impressive growth was that of coho so trout breeding was discarded due to its lower economic value. The breeding process was rudimentary, requiring substantial improvisation. One of the past caretakers, explained:

"I rowed to the cage routinely two times a day for almost three years. Each time I fed the fish with five kilos of pelleted fish meal, and once a week we measured some fish. The cage was pretty small so I could manoeuvre it on my own. I had an assistant for some time but she ... [Doña Eugenia]... couldn't afford salaries for two workers. We constantly had to improvise. Many times we ran out of food, so I went fishing and fed them with smashed fish. Once when we were 
completely out of food stock, I fed them...[carnivorous fish]...with rice! They always did well and after gaining some weight the Japanese came and released them. They ... [the Japanese] ... just wanted to make sure that they could be grown here".

The project came to an end following fish loss from a storm, financial difficulty, and sea lion damage. Nevertheless despite its apparent failure, inter-subjectivity was developing through practice. According to the caretaker, the event taught that when salmon reach a certain biomass their size makes them irresistible prey for sea lions. In Puerto Cisnes, the sea lion attack is remembered as an issue of public concern, being perceived as a fatal blow for the first salmon farm. However is clear that the social is in the salmon-public intimate associations.

The Japanese project sought to determine the viability of salmon ranching in southern Chile (Shimazu and Puchi, 1985). Information generated had two messages for fish farming companies: that the quality of the water in Puerto Cisnes was excellent for salmon breeding and that the human population familiar with aquaculture could provide a workforce. Returns were low so the experiment was deemed a failure, nevertheless it set a precedent, generating knowledge and skills for subsequent commercial salmon farming: qualified personnel trained in Japan, hatchery technologies adapted, and local hydrological conditions, salmon physiology and behaviour studied (Basulto, 2003; Vergara et al., 2004). It was also the first aquaculture concession requested by a municipality in Patagonia for salmon farming, with local people becoming skilfully engaged in the daily practice of fish feeding and dealing with the contingencies of this novel activity, developed skills and relations of affect for the longterm process of salmon domestication and industry development. 
Description of experiments to breed salmon and trout in captivity and of local peoples' engagement with these experiments, highlight new human - non-human alliances and intersubjectivities, as a salmon-public forms within the region. The creativity and experience of local people fed into the transformative potential of a field of relations: sea, fjords, net pens, boats, scientists, salmon, administrators, workers, the power and positioning of Doña Eugenia, plus flows of daily feeding and scientific observation, each bringing one another into material existence.

\subsection{Contingent encounters an the imperceptible change}

The second woman in our account is Doña Quina. She and her husband settled on Isla Tortuga, an hour by boat from Puerto Cisnes, in 1942. In 1989, 5 years after the breeding experiment described in Section 4.2, Doña Quina was a widower and amongst the last residents of the island. One day her son-in-law, Don Luis, received a visit from his neighbour, Don Pedro, asking him to transport two visitors from the capital, Santiago, who wanted to search for fish farming sites. He accepted and embarked immediately.

After some hours, Don Luis suggested visiting his mother-in-law to rest. She offered them tea and when one of the guests, Señor Ortúzar, described the fish farming plan she enthusiastically replied that Punta Tortuga was the best place to breed salmonids. Surprised, the group accompanied her to a river. She said:

"I have personally fed trout - salmoncitos - in this stream with chunks of bread.

They came upstream and settled in this natural pond. They quickly got used to me just like chickens do ... when they see people, now they start jumping for food". 
This is another illustration of how salmon were becoming part of everyday life, with intersubjectivity and social malleability emerging in representation of salmon as like chickens. According to Doña Quina, Punta Tortuga offered mild waters where salmon species could grow in ideal conditions. She pointed out that although people from Puerto Cisnes were not fishermen before the boom of hake fisheries, locals had always angled salmoncitos, los naturales in lakes and rivers.

In subsequent weeks, Señor Ortúzar dropped by her home again. As Don Luis explained: "He was fascinated by the vision of this old woman. Her enthusiasm was one of the things that pulled the trigger. Moreover, the few people who knew about his idea in Puerto Cisnes had expressed disbelief that something like this could be done and thought the chap was full of hot air".

Señor Ortúzar brought workers to construct experimental cages with Doña Quina steering the process. When she recommended the wood of Ciprés de las Guaitecas as the most water resistant he laughed and told the workers to do whatever she advised. Don Luis recounted: "Following the experiment he asked my mother-in-law: What do you think about me coming here to Tortuga to run a hatchery and a fish farm? Her answer was decisive: I have no problem, how could I be an obstacle to something that will bring jobs to the town. She offered use of the beach along her land as a base for future operations and gave her word with a handshake".

A year later Señor Ortúzar returned. Bringing workers and metallic cages, he established a base on Doña Quina's land. This was the origin of Centro Tortuga, the first seawater fish farm in Puerto Cisnes; it also consolidated the material formation of a salmon-public. 
Don Luis narrated an account that highlights how capital and technology joined local knowledge and environmental properties to produce salmon:

"And soon the fingerlings arrived. They arrived at the wharf in Cisnes by truck, having travelled all the way from Coihayque along 193 kilometres of dirt road in plastic tanks. Everything was done very carefully with fear at every step; no one had experience in handling fingerlings properly! They placed them in a small cage in the water and dragged it along by ferryboat. A trip you normally make in one hour took the whole day so as to avoid having the cage to sink too much, or float too much or pull the shoal too fast, all of which would have damaged the fingerlings. It was a logistical nightmare... But they finally succeeded. Nobody really knew a thing about this activity. I went back to my job in the fishery and a year later I met Señor Ortúzar for the second time and he asked me to go with him to visit Centro Tortuga. Fish were ready for harvesting and that is when he offered me work with the company, as a skipper of the company's new ferryboat. I had never piloted a barcaza before but I said 'yes'. It was an opportunity to get a job closer to where my family was. The ferryboat was baptised 'Doña Quina'.'

The first fish harvest of 1990 was considered remarkable. First, they unloaded a shipment of ice and carried it on their shoulders to the ferry and then to Centro Tortuga. The harvest taskforce was a team of 15 people. Harvesting took place after sunset when the temperature drops, making fish quieter and reducing decomposition. They started to catch fish: one team knocked the fish out with sticks, others sliced the gills and placed them in a bin to bleed to death, a third team packed slaughtered fish into Styrofoam boxes filled with ice. After completing 200 boxes, the ferryboat went to Puerto Cisnes and transferred the salmon to a truck for Puerto Chacabuco, where a hake exporter, subcontracted for the purpose, processed 
them. The ferry boat went back and forth four times and people worked until $4 \mathrm{am}$. They harvested 160 tons of Pacific salmon, far more than initial projections. As Don Luis described:

"Everything about harvesting was subject to minute by minute experimentation, as well as the result that came next day. Workers and managers were eager to know what had happened with the fish harvested the night before. Chacabuco was six to seven hours away by truck and the road was awful. Of course, it turned out that the quality wasn't good. The fish were full of bruises and scale-less because of the intensive manipulation. Regardless of the quality issue, due to inexperience, the results were good for the company".

From this success and without services or infrastructure, the company invested in a series of facilities, creating a hatchery and two worker camps within the fjord. Most productive activity was organised round securing supplies for the fish farms, primarily fishmeal, which was done by a task force of 30 men that unloaded and loaded up to 14 tons of sacks for each farm on their shoulders. In addition, each farm had a permanent crew of about 14 men for the time consuming labour of manual feeding. During the early 1990s, the workforce rose to 300 people. Don Luis and his boat "Doña Quina" served as maritime transport between Puerto Cisnes, the fish farms, and worker camps.

This account highlights contingent elements of social change: Doña Quina's role reveals how local knowledge was involved in identifying the potential of salmon farming. Capital and technology are decentred by contingency: chance led the company boss to Doña Quina and to value her opinion, identifying a location for salmon farming. An alliance is formed and intersubjectivity built from where the materiality of bio-power is established; a handshake sealed 
the potential of the first harvest, an affect leading to an agreement, which in turn leads to further territorialisation of the regional assemblage. The event did not produce salmon of quality for international markets, but stimulated the territorialisation of bio-power in the region through the intensive experience of salmon farming.

\subsection{A global business: The flow of Chilean-Norwegian relations}

So far our concern with Chilean Patagonia has focused on affect within the region; now we turn towards global alliances that stimulate a new line of flight. To do this we take the example of two entrepreneurs who were important in transforming the aquaculture industry in Chilean Patagonia, Mr Thomsen and Mr Ross. ${ }^{9}$

Mr Thomsen was born in Norway in 1954 at a time when salmon farming was developing, so he studied fishery economics. Mr Ross was born in Chile in 1964, the son of an Eastern European immigrant engineer who worked for a ship-building company, he studied biology. Through early careers, each man built up expertise on the fishing industry. In the mid-1980s Mr Thomsen, his father and brother formed a salmon farming enterprise 'Thomsen Invest'. He also held a succession of roles within the industry: Fishery Advisor for the Norwegian Fisheries Directorate, Political Secretary in the Ministry of Fisheries, Secretary General of the Norwegian Fish Farming Association, Chair of the Federation of European Aquaculture Producers and Chair of the International Salmon Farming Association; roles that led him to meet Chilean counterparts.

Mr Ross also combined directorship of his own company with industry roles. In 1986 he visited Norway on an internship related to technology transfer in the salmon industry. This

\footnotetext{
${ }^{9}$ Pseudonyms are used for people and companies.
} 
trip was the first time our actors met. On returning home he formed 'South Pacific', one of the first Chilean salmon farming industries. His company took the risky decision to expand into Chilean Patagonia, which was viewed as paradise for salmon farming but an infrastructural nightmare. He was also instrumental in building the Chilean Salmon Farmers Association.

In 1991 the Norwegian fishing industry faced a crisis triggered by market and financial constraints compounded by the monopolistic Fish Farming Sales Organization. This led to bankruptcies and triggered political and industrial change over ownership rules and business scale to facilitate investment (Aarset, 1998). This was controversial: Mr Thomsen's role in the Fish Farming Association meant he represented small-scale fish farmers, however he recognized "the only way out of the crisis was to open up to major players which could finance business growth". His shifting interests led him to move into the private sector, to become the manager of the aquacultural division of the largest food producer in Norway and eventually, through acquisitions and mergers, created the largest Norwegian aquaculture feed company.

In 1997 Mr. Thomsen decided to dedicate himself to the family business: "we decided to grow both locally and to build an international company". With four licenses in 1997, he enrolled other local fish farmers and in 1998 they obtained 20 licenses and changed the company's name to 'Northern Seafood'. Investors enabled international expansion; however this was conditional on the company being listed on the Oslo stock market, with the danger of a takeover bid: "We didn't have the money for the steps needed. Yes, we lost control, but that was the option we had in order to grow. I accepted those conditions. The alternative was to stay as a medium size family business". Mr. Thomsen became Chief Executive Officer and 
his brother remained as Operation Manager. "Just to give you an impression how fast we were growing, in four years we went from 5 million euros to 500 million, from 20 employees to 4,000 employees. That was a huge challenge. And we went from a family business to a company with a thousand shareholders".

Potential for development of the salmon industry in Chile was central to Mr. Thomsen's strategy: "I'd been traveling to Chile between 1990 and 2000 and I had a lot of business friends there. I'd been visiting farms. I'd seen the whole process, the good conditions from Mother Nature, and the openness of invitations to investors". The European market was to be supplied by Norway, but the Japanese and the U.S. markets were to be targeted through Chile, taking advantage of free trade agreements. In 2000, once the Company was listed on the Oslo Stock Market, Mr. Thomsen went to Chile to talk to his "business friends", including Mr. Ross. This led to two Chilean companies being taken over and merged under the name of the mother company, now called 'Northern Seafood'. This was the first Norwegian company of many to invest in Chile.

Mr. Ross was also taking important decisions. In 1999 salmon prices dropped and the optimism of unlimited growth faded. Moreover, the consequences of a geographically concentrated industry were apparent: fish health outbreaks, harmful algae blooms, environmental opposition, and spatial competition. The future was investment in new areas along the Patagonian fjords and islands of Aysen region, with quality coming to the fore as a driving concept. Mr Ross regularly traveled to Norway and with the idea of quality improvements he paid attention to two inter-related technologies that would be decisive in the expansion in Patagonia: the live-harvest system (or well-boat, Figure 3) and the live-slaughter 
system. ${ }^{10}$ Using his father's shipyard, Mr Ross adapted a vessel for use as a well-boat, its success led to the creation of 'South Pacific Well-boats', equipping boats with the latest technology.

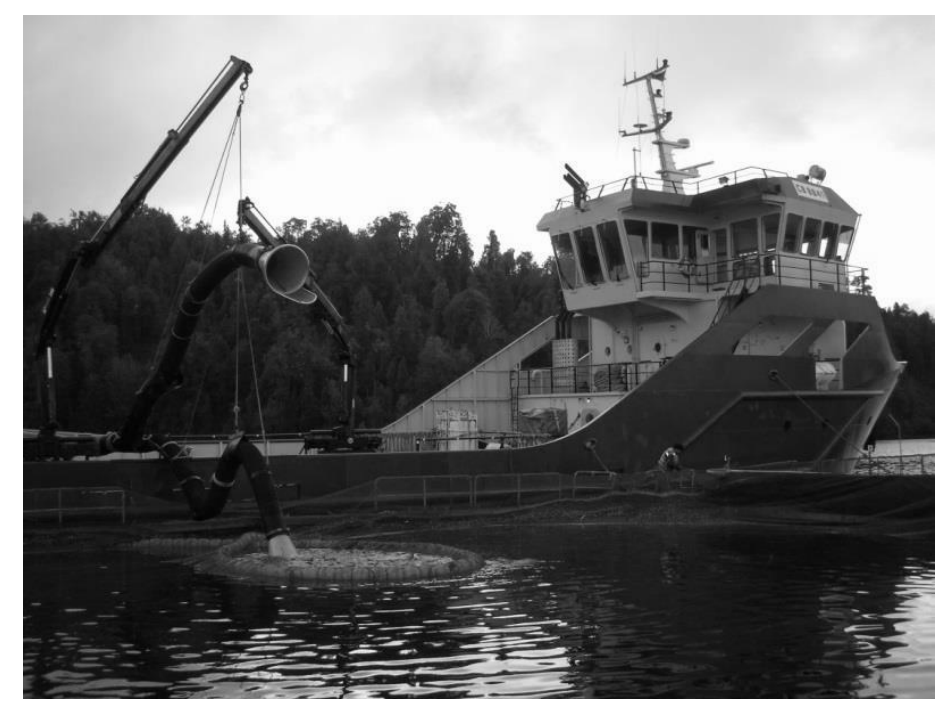

Figure 3: Well-boat harvesting fish in the Puyuhuapi ford.

Every well-boat was contracted by other salmon farming companies to provide live-harvest services; clients were companies awaiting the development of Aysen's infrastructure. This was a logistic revolution: absence of land-based infrastructure in Aysen was by-passed using Chiloé (in the northern Los Lagos Region) as the platform for operations. Having stimulated this change, Mr Ross sought to use the Patagonian facilities to produce juveniles to supply the growing demand from provision of well-boat services while keeping 'South Pacific' as a medium-size company oriented to premium and niche markets. He was the first to introduce technology regarding quality, which helped overcome infrastructural constraints in Patagonia.

\footnotetext{
${ }^{10}$ Live fish are pumped onto a well-boat to be transported to a supply center near the processing plant, reducing logistic, environmental and quality inconveniences. With the live-slaughter system rigor mortis is reduced to improve quality.
} 
The roles of Mr. Thomsen and Mr. Ross in salmon industry development is to capture relations of affect to permit the resonance of capital and technology as the machine that established the salmon industry in the Patagonian region, though the process also included to varying degrees, contingent elements and relations between global entrepreneurs and local people. Degrees of latitude and longitude reveal an assemblage whose dimensions are ideally suited to salmon production for the global market, with features such as new technology overcoming logistical difficulties. However, capital and technology seem insufficient to explain its emergence and amplifications to the public. Nevertheless material properties of the industry when under way, introducing within a territory potential for self-destruction of the expressive components of the assemblage: fish disease, environmental threat, and competition, as recognized in a canny entrepreneur's concern over quality and this made a real difference in the region for good and ill.

\subsection{Aysen: 'The salmon-public region'}

We have progressively revealed the constitutive practices that have shaped the Patagonian Region as an assemblage, practices that situate salmon farming as a distinctive realm in regional transformation and identity, indeed Aysen is widely referred to as 'the salmon region'. In this section we focus on contemporary salmon workers' practices, locating them as the material and public expression of a globally-oriented, salmon industry. One can suggest that the content of these working practices reorients actors' inter-subjectivity towards the material and temporal, insofar as these practices are an outcome of the quasi-actant we refer to as the salmon-public, creating alliances that bring together relations of movement, rest, speed and slowness within an assemblage. The intensive affects emerging from people's movement between the land, sea and technology, create diverse expressions of intentionality. 
In the $21^{\text {st }}$ century, salmon farming is an advanced technological proposition. Most salmon companies are organised according to vertical integration of production, separated into 6 stages: fresh water hatchery, brood-parr-smolt rearing facilities, sea transfer, seawater fishfarms, slaughter, and processing, with further forward integration for sales and marketing. To identify contemporary practices within the production chain, we take the example of the seawater fish-farm stage of one company 'GrandSalmon', which has been based in Puerto Cisnes since 1989 and organises its fish-farms within two sites, at Puerto Cisnes and at Melinka. At the time of research, GrandSalmon ran 22 fish farms, although there were plans to double the number over the next two years with an investment of US\$20 million. For such a strategy, they already had 56 site concessions and another 175 in the process of being granted by the authorities.

During the fieldwork, we conducted an interview with Manuel, a 33 year old fishing engineer from Valparaíso, now living in a company house in Puerto Cisnes with his wife and daughter. With 10 years-experience in salmon aquaculture, 4 with GrandSalmon, Manuel started as Farm Production manager but, due to his ability to sort out different crises, was upgraded to General Manager of Production. Manuel explained that 1998 marked a milestone in business strategy for GrandSalmon: at the time it was close to bankruptcy, however the mother company, a large agro-food holding, decided to continue salmon farming with a drastically transformed production rationale:

"At that time we internalized that we were not producing fish but food. It is a change that makes a tremendous difference and triggered several measures in order to put it to work. Before, managers and personnel were in a struggle to decipher fish production. Now, we assumed we belonged to a high standard holding of food production. The salmon branch of the company was taken out of 
bankruptcy and step-by-step we are becoming a big player in seafood production."

Reorganization meant firing staff and placing managers from the pork and chicken industry in key positions. It was also the beginning of outsourcing and standardization processes. At the offices of GrandSalmon, management work at modular desks on the second floor looking out to sea, with walls covered with maps marked by pins in three colours to highlight sites with active farms, fallow farms and plain concessions. Each manager keeps a life jacket and rubber boots beneath his desk for field trips. There is a symbolic division between office staff (management and clerks) and fish-farm workers. Office staffs wear light blue shirts with the company logo embroidered on the pocket; workers do not. Alongside interviewing Manuel, time was spent with four other production managers at the Company offices. None of them was older than 33 and only Manuel had been with GrandSalmon for more than 3 years; all came from outside the region. Each production manager visits fish farms on a daily basis and a common feature of the four managers was that they are always on the move by a different means of transport. Domingo, for example, was going the following day by boat to Melinka due to a disease outbreak, three days later he would take an aircraft to meet the General Manager in Puerto Montt and afterwards travel by car to Temuco to visit a hatchery. A week later he was to join Manuel on a flight to Santiago to explain the yearly production plan to the Company's board.

For GrandSalmon, each production stage is a separate unit with its own staff and accountability for inputs and outputs; nevertheless they follow centrally designed planning and timing to deliver products to the next unit. Over a production cycle of approximately 3 years, the circulation of salmon is as follows: After spawning and hatching, fresh water 
fingerlings are moved to salt water as 'smolts', which are physiologically ready to grow at sea, where they are based on seawater farms until they reach commercial weight. After 9-13 months, fish are harvested and sent to the processing plant. Amounts of fish harvested are set in advance, satisfying global contract demands.

At Melinka, GrandSalmon uses technologically intensive pontoons to farm the salmon. The following ethnographic data is based on a trip to a pontoon: A high speed catamaran, the Sognekongen, belonging to a Norwegian company showed up at the embarkation point and salmon workers quickly gather, identifiable in waterproof jackets carrying life vests (Figure 4). After three hours of pitching and rolling, the catamaran approached the isolated village of Melinka - a settlement that flourished in the nineteenth century for the timber trade, now witnessing a salmon boom.

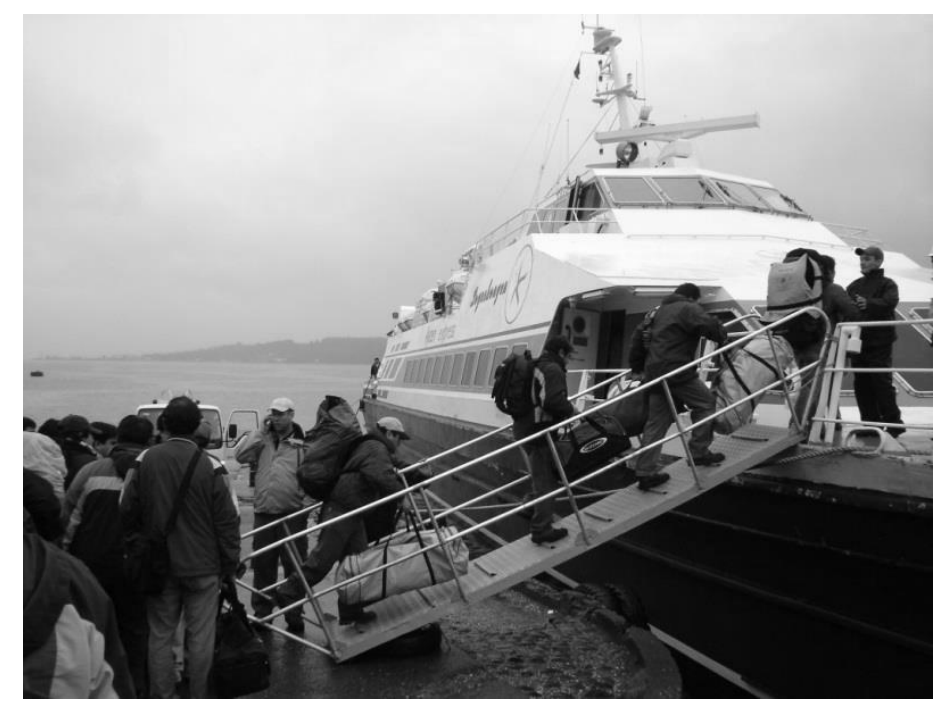

Figure 4: Fish farm workers on their daily way to work

During the trip we interviewed Gabriel, a 34 year old fishing engineer from Santiago and one of 6 seawater-farm chiefs in Melinka. The shift system for those in more isolated settings is either $14 \times 7$ (fourteen working days and 7 off) or $21 \times 10$ respectively and at the time of the 
interview he was coming back from a week with his family. He confessed he detested the time spent travelling:

"It happens that I really feel at home when I arrive at the pontoon. It might sound terrible, but it's the way I feel. Of course I miss my family but, after all, I spend most of my time at the pontoon with my team mates."

With ten years in salmon farming and in four different companies, he had already earned the reputation of veteran, who had witnessed the expansion of salmon farming in Patagonia: "For you, as a visitor, it is easy to see how aquaculture is currently being practiced in this region. For us, and for the people of Melinka, the changes have been incredible and have taken place at an amazing speed. This was a village lost in the middle of nowhere and now there is a buzz of activity. It would have been unthinkable, without the technology and money invested, to expand operations in the archipelago."

As we neared the pontoons, spots of light showed on the dark horizon, and as we drew close we observed a house-like 3 storey structure full of windows, which look out onto the fish platforms that extend into the ocean (Figures $5-6$ ).

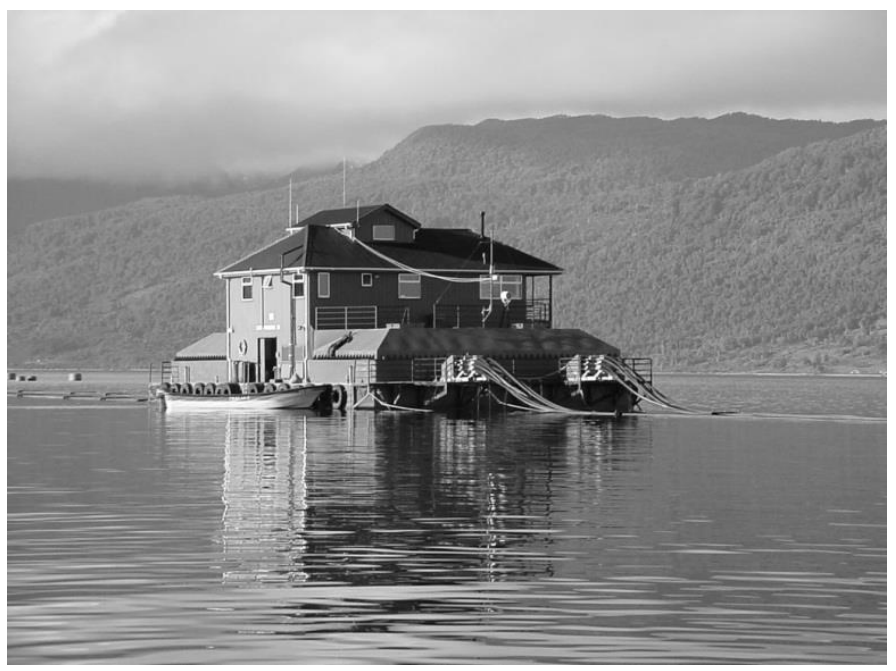

Figure 5: Fish farming pontoon 


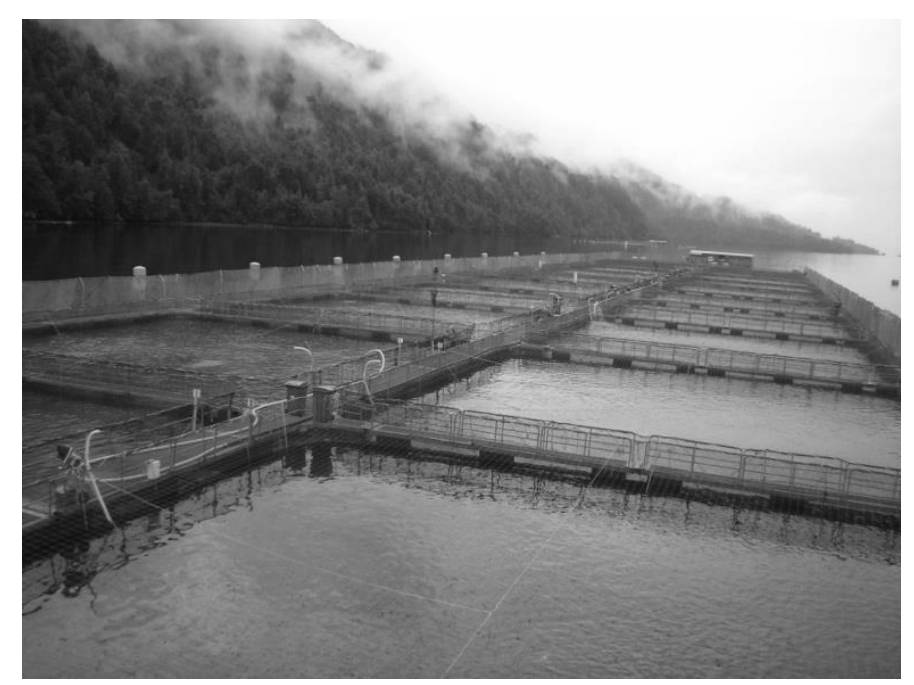

Figure 6: Fish farm

At the pontoon the main routine tasks of the staff are controlling the right level of inputs needed for keeping fish production going: fuelling oil to the generators, fish meal to the blower's tank and butane cylinders onto the motorboat, watching the submarine cameras to control fish feeding behaviour and adjust the software if necessary. In addition, a foreman is responsible for people's needs, and for supplies, keeping inventory records, sending reports to headquarters, and overseeing contracted services. Each day workers are left on the fish platforms with staff moving between platforms and pontoons by motorboat, intercommunicating by walkie talkies. With automatic feeding, routine tasks include supervising the function of blowers, checking fish behaviour and receiving a daily team of divers to extract dead fish and conduct maintenance.

This brief description of the company offices and working on a pontoon shows individualities and multiplicities formed from on-going routines and the establishment of bio-power. The interaction of these elements of a region within the plane of 'nature' does not permit classification and reduction of salmon to the category of a non-human actor. Instead, as a 
quasi-actant it directs us towards the ontological expression of the social, which includes affects, practices and not just attached categories of discontinuous being, but the fibril of nerves of the salmon-public alliance. Working on salmon farming pontoons, travelling long distances by sea, land and air, and following new forms of labour shift are all part of the routinize contemporary aquaculture and the outcome of the intensity of becoming that takes place in the constitution of a region. Becoming intensively global, oriented towards 'biopower' and at the same time incorporating people's working practices, family life, and desire for proximity and sharing between humans and non-humans The region and the salmonpublic reverse each other in terms of materialities; entering into an alliance of content and expression. Interfaces are created as actualizations of a regional form that expresses global multiple ways of life and the specificity and variability of inter-subjective relations.

\section{Conclusions}

This article has used assemblage theory to examine the salmon industry in Chilean Patagonia. Original ethnographic data has permitted exploration of the potentiality of human - nonhuman relations in regional transformation. Lines of flight have been followed, moving through identification of a 'vacant ecological niche' and the translocation of an 'alien species', stimulated by sports-fishing interests, to settlers' establishing close relationships to the sea and fjords and the start of scientific experiments and technology transfer. This established the basis for later alliances between Chilean and Norwegian entrepreneurs, stimulated by learning from other industries, and enabled salmon farming to expand rapidly into Chilean Patagonia, linked to technological change, market segmentation and emphasis on quality. Physical characteristics of Patagonia have shaped territorialisation processes remoteness, absence of land-based infrastructure, the marine environment - as has the way 
technology has been used to advantage within this terrain - the well-boat, pontoon, and seawater net-pen.

At the start of this article, we asked whether an assemblage approach sensitive to intersubjectivity can improve understanding of regional transformation for global food production. In our view, an assemblage approach provides a conceptual entry point to frame empirical data that decentres the proposition that regions are the result of rational institutional practices underpinned exclusively by the driving forces of capital and technology, instead bringing to the fore material, transversal associations and events. Methodologically, we have presented several events that constitute a place of consistency, recognising processes of appropriation and how multiple actors are incorporated into the lifeblood of salmon production. Our analysis is facilitated by creating symmetries between different actors' - e.g. local women, in-coming capitalists, and salmon - while recognising that the growing potentiality of bio-power creates new asymmetries of power. As genetic commoditised data, salmon-public alliances, appropriation of knowledge, viruses and other bio-entities shift power relations and stimulate new lines of flight, contributing to the imperceptibility of regional becoming. In effect an 'aparallel evolution' between the human and non-human has led the idea of the region and the materiality of the salmon to take shape publically, scrambling any lineal cause and effect genealogy of the region and salmon.

Regional transformation has generated a social field marked by fluidity, leading us to ask where the social resides contra perspectives placing emphasis on inter-objectivity and social constructivism. As social scientists we seek to bring the social to the fore while rejecting the idea that people - salmon alliances are 'actor-centred', and it is here that we have placed emphasis on the creative potential of processes of inter-subjectivity. We have used a methodological device to characterise this inter-subjectivity, a quasi-actant - the salmon- 
public - because human coexistence takes place as part of and amid the arrangements of actors and other phenomena and therefore is not the pivot around which entities gyrate. Paying attention to inter-subjectivity we locate regional studies within a new sociology of associations, as an assemblage emerges from a series of events, which are neither inside subjects nor outside them.

Assemblages are the fibril of nerves, the sensitivity that connects humans and non-human subjects to the region. The social is the culmination of intersubjective practices, actions and interactions and resides within the instituted continuous and discontinuous practices and resources mobilised, it is in this plane the salmon-public alliance is formed and flows. In effect, it is in the return of the social that the inter-objective dimension becomes relevant for a region in which a variety of modes of being institute encounters and sustains relationships. These we argue are different from traditional global and local dichotomies.

We recognise there is no sociology or anthropology without the study of alliances with the non-human. However, this shouldn't lead to the automatic conclusion that there is no distinction between different ontological world-encounters. This raises the need to study heterogeneous associations of human and non-human actors to appreciate different natures and socials, in order to describe and analyse the ways in which social life is mutating by these various degrees of creative associations. As it is the case in the emergent bio-regional formation, this does not obliterate human - non-human distinctions but instead working with entities and actors in a relational way redirects and redistributes agency and not just objectivity. In this respect, this conceptual- ethnography has captured how practices unfold over time through experiential encounters between Salmonidae and people, as manifest 
through public classifications, in the in-folding of materiality within the constitution of regions.

Relational ontology has allowed us to go beyond the notion of interaction between singular actors and the straitjacket of a linear regional planning trajectory to observe how matter becomes shaped with different degrees of vitality, foregrounding the overlapping of worlds between different actors, which eventually become territorialised. One expression of this process is a region.

\section{Acknowledgements}

We would like to thank the Editor, two anonymous reviewers, the Wageningen Ontology Group, and several colleagues for comments that helped to improve our argument. 


\section{References}

Aarset, B., 1998. Norwegian salmon-farming industry in transition: dislocations of decision control, Ocean and Coastal Management 38:187-206.

Allen, J., 2011. Powerful assemblages? Area 43(2):154-157.DOI:

http://dx.doi.org/10.1111/j.1475-4762.2011.01005.x

Allen., Massey, D., and Cochrane, A., 1998. Rethinking the region. Routledge: London.

Amtmann, M. and Fecci, E., 2008. Competencias laborales de la industria salmonera y mano de obra rural en la Comuna de Dalcahue, Provincia de Chiloé. Esudio de caso, in Pérez, E. Farah M.A. and Grammont H.C. de (eds.) La Nueva Ruralidad en América Latina: Avances Teóricos y Evidencias Empíricas. Pp. 269-287. Pontificia Universidad Javeriana-CLACSO: Bogotá.

Anderson, K., 1997. A walk on the wild side: a critical geography of domestication, Progress in Human Geography 21(4):463-485.

Arce, A. and Long, N., 2000. Reconfiguring modernity and development from an anthropological Perspective, Arce, A. and Long, N. (eds.) Anthropology, Development and Modernities: Exploring discourses, counter-tendencies and violence. Pp.1-31. Routledge: London.

Barret, G. Caniggia, M. Read, L., 2002. 'There are more vets than doctors in Chiloé': Social and community impact of the globalization of aquaculture in Chile, World Development 30(11):1951-1965.DOI:http://dx.doi.org/10.1016/S0305-750X(02)00112-2

Barton, J., 1997. Environment, sustainability and regulation in commercial aquaculture: The case of Chilean salmonid production, Geoforum 28(3-4):313-328.

Basulto, S., 2003. El largo viaje de los salmones. Una crónica olvidada. Propagación y cultivo de especies acuáticas en Chile. Santiago: Sernapesca.

Bennett, J., 2010. Vibrant matter: A political ecology of things. Duke University Press: Durham.

Bjørndal, T. and Aarland K., 1999. Salmon aquaculture in Chile, Aquaculture Economics and Management 3:238-253.

Blanco, G., 2009. The social life of regions: Salmon farming and the regionalization of development in Chilean Patagonia. PhD thesis, Wageningen University.

Blanco, G. and Amtmann, C., 2001. Efectos de la salmonicultura en las economías campesinas de la Región de Los Lagos, Chile, Revistas Austral de Ciencias Sociales 5:93106.

Bloor, D (1999) Anti-Latour, Studies in History and Philosophy of Science, 30(1):81-112. 
Bowker, G.C. (2005) Time, Money, and Biodiversity, Ong, A. and Collier, S. (eds.). Global Assemblages: technology, politics and ethics as anthropological problems. Pp 107-123. Blackwell Publishing: Oxford.

Braidotti, R. 2013. The Posthuman. Polity Press: Cambridge.

Braun, B. 2014. New Materialisms and Neoliberal Natures, Antipode 47(1): 1-14.

Buschmann, A., 2005. Marea Roja y salmonicultura en el sur de Chile. Documento 14. Santiago: Oceana.

Bustos-Gallardo, B., 2013. The ISA crisis in Los Lagos Chile: A failure of neoliberal environmental governance? Geoforum 48:196-206.DOI:

http://dx.doi.org/10.1016/j.geoforum.2013.04.025.

Claude, M. and Oporto, J., 2000. La ineficiencia de la salmonicultura en Chile: aspectos sociales económicos y ambientales. Santiago: Terram Publicaciones.

Collins, H.M., and Yearley, S. 1992a. Epistemological Chicken, Pickering, A. (ed.) Science as Practice and Culture 301-326. Chicago University Press: Chicago.

De Landa, M., 2006. A new philosophy of society: Assemblage theory and social complexity. Continuum: New York.

Deleuze, G. and Guattari, F., 1988. A thousand plateaus: Capitalism and schizophrenia. Athlone Press: London.

Deleuze, G. and Parnet, C., 2002 [1977]. Dialogues II (translated by Tomlinson, H. and Habberjam, B.) Continuum: New York.

Dewey, J., 1954 [1927]. The public and its problems. Swallow Press: Athens.

Dittmer, J., 2014. Geopolitical assemblages and complexity, Progress in Human Geography 38(3): 385-401.DOI:http://dx.doi.org/10.1177/0309132513501405.

Dunlap, T. R., 1997. Remaking the land: The acclimatization movement and Anglo ideas of nature, Journal of World History 8(2), 301-319.

Forster, J., 2002. Farming Salmon: An example of aquaculture for the mass market, Reviews in Fisheries Science 10(3-4), 577-591.

Foucault, M. 1978. The History of Sexuality. Volume I. Pantheon Books: New York.

Franklin, A. S., 2011. Performing acclimatization: The agency of trout fishing in postcolonial Australia, Ethnos 76(1): 19-40.DOI: http://dx.doi.org/10.1080/001418.44.2010.537759.

Franklin, S., 2008. Stem Cells R Us: Emergent Life forms and the Global Biological. In Ong, A. and Collier, S. (eds.) Global Assemblages: technology, politics and ethics as anthropological problems. Pp 59-78. Oxford: Blackwell Publishing. 
Gajardo, G. and Lairke, L., 2003. Chilean aquaculture boom is based on exotic salmon resources: A conservation paradox, Conservation Biology 17(4), 1173-4.

Godoy, M.G. Aedo, A. Kibenge, M.J.T. Groman, D.B. ' Yason, C.V. Grothusen, H. Lisperguer, A. Calbucura, M. Avendaño, F. Imilán, M. Jarpa, M. and Kibenge, FSB., 2013. First detection, isolation and molecular characterization of infectious salmon anaemia virus associated with clinical disease in farmed Atlantic salmon (Salmo salar) in Chile.

Golinski, J., 1998. Making Natural Knowledge: Constructivism and the History of Science. Cambridge University Press: Cambridge.

Goycoolea, L. and Sandoval, R., 2003. Chile, la aventura de pescar con mosca. Santiago: El Mercurio/Aguilar.

Guattari, F., 1995. Chaosophy, Lotringer, S. (ed.) Semiotext(e) Foreign Agents Ser. New York: Semiotext(e).

Ingold, T., 2011. Being alive: essays on movement, knowledge and description. Routledge: Abingdon.

Katz, J., 2004. Economic, institutional and technological forces inducing the successful inception of salmon farming in Chile. DFID/World Bank.

Kohn, E., 2007. How Forests Think. University of California Press: Berkeley.

Krarup, M. T \& Blok, A., 2011. Unfolding the social: Quasi-actants, virtual theory, and the new empiricism of Bruno Latour, The Sociological Review, 59(1):42-63.

Knudsen, S., 2014. Multiple Sea Snails: The Uncertain Becoming of an Alien Species, Anthropological Quarterly, 87(1):59-91.DOI:10.1353/anq.2014.0013.

Latour, B., 2005. Reassembling the Social: An Introduction to Actor-Network-Theory. Oxford University Press: Oxford.

Lever, C., 1994. Naturalized animals: The ecology of successfully introduced species. T and A.D. Poyser: London.

Li, T.M., 2007. Practices of Assemblage and Community Forest Management, Economy and Society 36(2): 263-293.

Lien, M.E. and Law, J., 2011. 'Emergent aliens': On salmon, nature, and their enactment, Ethnos 76(4): 65-87.DOI:10.1080/00141844.2010.549946.

Lien, M.E., 2005. 'King of fish' or 'feral peril': Tasmanian Atlantic salmon and the politics of belonging, Environmental Planning D: Society and Space 23: 659-671.DOI:10.1068/d352t

Lindbergh, J., 1999. Salmon farming in Chile: Do the benefits exceed the costs? Acquaculture Magazine 25(2):33-37.Marres, N.S., 2005. Issues spark a public into being: a 
key but often forgotten point of the Lippmann Dewey debate, in Latour, B. and Weibel, P. (eds.) Making things public: atmospheres of democracy. Cambridge, MA: MIT Press.

McFarlane, C. and Anderson, B. (2011) Thinking with assemblage, Area, 43(2)162-164. DOI: $10.1111 / \mathrm{j} .1475-4762.2011 .01012 . x$

Metzger, J., 2013. Raising the regional leviathan: A relational-materialist conceptualization of regions-in-becoming as publics-in-stabilization, International Journal of Urban and Regional Research 37(45):1368-95.DOI:10.1111/1468-2427.12038

Montero, C., 2004. Formación y desarrollo de un cluster globalizado: el caso de la industria del salmón en Chile. CEPAL: Santiago.

Navaro-Yashin, Y., 2009. Affective spaces, melancholic objects: ruination and the production of anthropological knowledge. Journal of the Royal Anthropological Institute $15: 1-18$.

Nikilitschek, E.J., Soto, D. Lafon, A., Molinet, C. Toledo, P., 2013. Southward expansion of the Chilean salmon industry in the Patagonian Fjords: main environmental challenges, Reviews in Aquaculture 5:172-195.DOI:101111/raq.12012.

Ong, A. and Collier, S. (Eds.), 2008. Global Assemblages: technology, politics and ethics as anthropological problems. Pp 59-78. Oxford: Blackwell Publishing.

Shimazu, K. and Puchi, M., 1985. The development of salmon stock in Aysen. Servicio Nacional de Pesca / JICA: Santiago.

Silver, J.J., 2014. Shellfish and Coastal Change: Pacific Oysters and Manila Clams in BC Waters, BC Studies, 181 (Spring):83-103.

Silver, J.J., 2013. Neoliberalizing coastal space and subjects: On shellfish aquaculture projections, interventions and outcomes in British Columbia, Canada, Journal of Rural Studies 32:430-438.DOI:10.1016.j.jrurstud.2013.10.003.

Thrift, N., 2008. Non-representational Theory: Space, Politics, Affect. Routledge: London and New York.

Umans, L. and Arce, A., 2014. Fixing Rural Development Co-operation? Not in Situations Involving Blurring and Fluidity, Journal of Rural Studies 34: 337-

3.DOI:10.1016.jrurstud.2014.03.004.

Van der Tuin, I. and Dolphijn, R., 2010. The Transversality of New Materialism, Women: A Cultural Review 21.2:153-714.DOI:10.1080/09574042.2010.488377.

Vergara, M. Martínez, S. Taub, S. Palacios, S., 2004. Aquaculture in Chile. Technopress: Santiago. 